\title{
The Effect of Pumice Sand as Fine Aggregate on Tensile Strength of Precast Concrete
}

\author{
Abd. Majid Abdullah ${ }^{1 *}$, Abdul Gaus ${ }^{2}$, Mufti Amir Sultan ${ }^{2}$ \\ ${ }^{1}$ Master Degree Program, Department of Civil Engineering, Universitas Khairun, Indonesia \\ ${ }^{2}$ Department of Civil Engineering, Faculty of Engineering, Universitas Khairun, Ternate, Indonesia
}

\begin{abstract}
In this study, a cylinder with a size of $15 \mathrm{~cm}$ x $30 \mathrm{~cm}$ totaling 10 pieces for the splitting tensile test. 5 pieces cylinder were used for the normal splitting tensile test and the other 5 pieces cylinder were used for the joint splitting tensile test were used. Two tests have been carried out, namely the normal splitting tensile strength (control) and the joint splitting tensile strength. In testing the tensile strength of the test object, the applied tool to provide the load is the Compression Testing Machine. The splitting tensile strength test was carried out on 10 test objects in the form of concrete cylinders with an age of 28 days. 5 test objects were used in the normal splitting tensile strength (control). Meanwhile, the other 5 test objects were used in the joint splitting tensile strength. The test objects were given the load gradually until the test objects experienced cracks or reaching maximum load.
\end{abstract}

Keywords: Tensile Strength, Concrete, Pumice Sand

\section{Introduction}

The development of transportation infrastructure, especially roads, is currently very fast. It is carried out to support the transportation system which is highly important for people, especially those living in the archipelagic region. Furthermore, this development is the most important element for increasing the welfare of the community [1][2]. The transportation sector can accelerate development in Eastern Indonesia. Specifically, the provision of road infrastructure using rigid pavements in the archipelagic region has several advantages over flexible pavement construction because its construction is simpler, easier to shape, more resistant to water, and requiring fairly low maintenance costs [3][4]. However, the use of rigid pavements in the archipelagic region like North Maluku is very lacking because its use cannot be separated from the problem of costs at the beginning of construction which is higher when compared to flexible pavements due to the material that must be imported from outside North Maluku [5].

Concrete that is worked elsewhere and joined at the construction site is called precast concrete. Many types of structures have used the precast system. Compared to reinforced concrete that is cast at the construction site, precast concrete has better quality, especially for fast and bulk work [6]. Besides, the use of precast concrete simplifies the work process, especially in densely populated areas and areas that are difficult to access with heavy equipment. Therefore, we need a construction design that has a good capacity for structural components and can be carried out quickly and efficiently [7].

North Maluku is an archipelagic region that is very rich in material from volcanic magma deposits. One of those materials is pumice sand (Indonesian: pasir apung (PA)). This material is estimated to have reserves of up to millions of cubic meters that have not been fully utilized, in addition to other materials, such as ordinary sand available which is very limited [8]. Although the pumice sand is widely available on the island of Tidore, it has not been fully utilized for construction materials. To date, people have only used it as stockpile and materials for making cement bricks (Indonesian: batu tela) [9]. For this reason, further studies are highly needed to utilize pumice sand as a basic material for making lightweight concrete so that it can be implemented in construction for concrete roads or buildings.

The connection in the precast structure is the most important element in transferring the force as an energy dissipation link between the precast components that are connected. Precast concrete has not been widely used because an error is still often encountered in the connection [10]. As a result, planning concerning the placement of the right size and strength of the connection is needed so that structural failure is not experienced.

Concrete is a material that is widely used to make building structures because the constituent material is easy to obtain and has many advantages over other materials. The specific gravity of concrete is one of the 
elements that is taken into account because it greatly influences the calculation of structural loading. Reducing the unit weight of concrete to gain a lighter specific gravity can be conducted by making concrete from lightweight aggregates, adding air, or adding materials that have a small unit weight [11]. Lightweight concrete is concrete that has a specific gravity which is less than $1850 \mathrm{~kg} / \mathrm{m}^{3}$ [12]. Lightweight concrete is an alternative to make the structural load used smaller because it has a lighter specific gravity. Its components are pumice added with styrofoam waste material. The use of pumice instead of coarse aggregate can create lighter concrete [13][14]. Lightweight concrete is formed by using aggregates that are relatively light, such as pumice sand, white cork, soil, and plastic waste, compared to the aggregates used to make normal concrete. Pumice sand is chosen as a material in a lightweight concrete mixture because it can absorb water on the surface and is easy to find and quite a lot in Tidore [15]. The weight of concrete can be reduced by up to $25 \%$ by using pumice as a mixed material compared to normal concrete. In addition, the weight can be increased again by modifying the aggregate in the concrete mixture. Furthermore, the shape of the beam connections can be varied by testing [16].

In precast concrete work, joints are always an obstacle, especially lightweight concrete. This problem is what is investigated in this study. Besides, North Maluku is an archipelagic area that possesses abundant pumice sand material that has not been used optimally. Therefore, pumice sand as the basic material for fine aggregate in lightweight precast concrete is expected to be applied to rigid pavements.

Materials resulting from volcanic magma deposits can be easily found in many areas of the Maluku islands. One of those materials is pumice sand which is very abundant in these islands. Pumice sand is one of the natural materials that can be used as fine aggregate which has a low density because it has a lighter weight so that it is suitable for use as a lightweight concrete mixture. Pumice sand is widely available on Tidore island and its aggregate varies in the form of stone/gravel (coarse aggregate) and fine-grained soil (fine aggregate).

Pumice sand is very suitable for fine aggregate in concrete mixtures because it contains a high silica composition between $52.30 \%$ and $65.60 \%$ [17]. For use as fine aggregate, sorting or sifting is carried out using a $4.75 \mathrm{~mm}$ diameter sieve. Figure 1 shows pumice sand that has been sifted so that it can be used as fine aggregate in lightweight concrete.

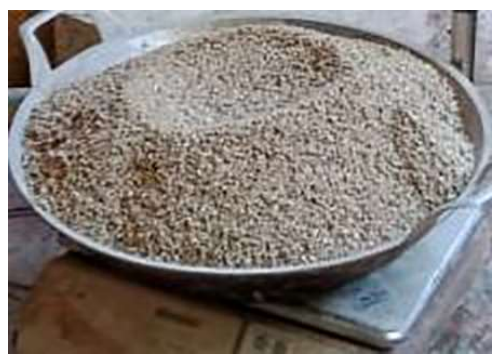

Fig.1. Pumice sand as fine aggregate
According to Indonesian National Standard (Indonesia: Standar Nasional Indonesia (SNI)), the magnitude of the concrete fracture stress can be calculated using the following equation [18].

$$
f r=\frac{2 \mathrm{P}}{\pi \mathrm{LD}}
$$

Where:

$$
\begin{aligned}
f r & =\text { tensile strength of the test object }(\mathrm{MPa}) \\
P & =\text { highest load read on the testing machine }(\mathrm{N}) \\
L & =\text { length of the test object }(\mathrm{mm}) \\
D & =\text { diameter of the test object }(\mathrm{mm})
\end{aligned}
$$

\section{Methods}

In this study, the researchers applied an experimental method carried out at the Materials and Concrete Laboratory of the Civil Engineering Study Program, Faculty of Engineering, Khairun University. For the tensile strength test, the researchers created cylindrical specimens from pumice sand as fine aggregate for making lightweight concrete. In the tensile strength test, the specimen was loaded until it was cracked or destroyed. Tensile strength test specimens were a normal cylinder as a control and a cylinder that was gradually cast $1 / 2$ perpendicular to the $\mathrm{x}$-axis to determine the tensile strength of the joint. In addition, this tensile strength test was to determine the shear strength of lightweight concrete.

\subsection{Test Objects}

In this study, the researchers used a cylinder with a size of $15 \mathrm{~cm} \mathrm{x} 30 \mathrm{~cm}$ totaling 10 pieces for the splitting tensile test. 5 pieces were used for the normal splitting tensile test and the other 5 pieces were used for the joint splitting tensile test. The shape of the test object can be seen in Figure 2. Furthermore, the variation of the test objects for two split tensile strength tests can be seen in Table 1.

Table 1. Variation of tensile test specimens

\begin{tabular}{|l|l|l|}
\hline Test Objects & $\begin{array}{l}\text { Variation of tensile } \\
\text { test specimens }\end{array}$ & Total \\
\hline TB1 & $\begin{array}{l}\text { Test objects for the } \\
\text { normal splitting } \\
\text { tensile test }\end{array}$ & 5 \\
\hline TB2 & $\begin{array}{l}\text { Test objects for the } \\
\text { joint splitting tensile } \\
\text { test }\end{array}$ & 5 \\
\hline
\end{tabular}

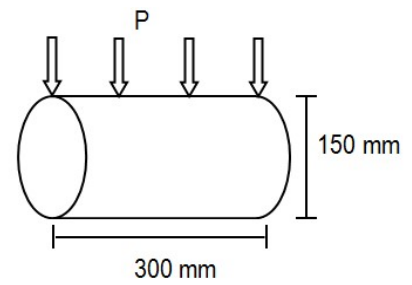

a. Test objects for the normal splitting tensile test 


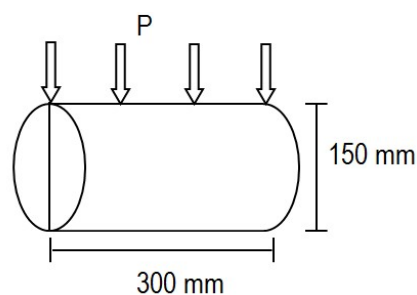

b. Test objects for the joint splitting tensile test

Fig.2. Sketch of Splitting Tensile Strength Test

\subsection{Testing the split tensile strength of concrete}

The test was carried out according to Indonesian National Standard [18] to determine the split tensile strength of the concrete specimen as shown in Figure 2. The steps for testing the tensile strength of concrete were as follows.

1. Prepare the test objects, namely the concrete cylinders.

2. Put the test object on the concrete tensile strength tester.

3. For the test objects of the joint splitting tensile test, set the pressure position on the joint line.

4. Turn on the concrete tensile strength tester and increase the load until the test object is destroyed.

5. Observe and record the results of the test.

6. Do all these steps to all test objects.

\section{Results}

Two tests have been carried out, namely the normal splitting tensile strength (control) and the joint splitting tensile strength. In testing the tensile strength of the test object, the applied tool to provide the load is the Compression Testing Machine. The splitting tensile strength test was carried out on 10 test objects in the form of concrete cylinders with an age of 28 days. 5 test objects were used in the normal splitting tensile strength (control). Meanwhile, the other 5 test objects were used in the joint splitting tensile strength. The test objects were given the load gradually until the test objects experienced cracks or reaching maximum load, as shown in Figure 3. The splitting tensile strength of the test objects was calculated using equation 1. After that, we found the maximum split tensile strength for each test object as presented in Tables 2 and 3.

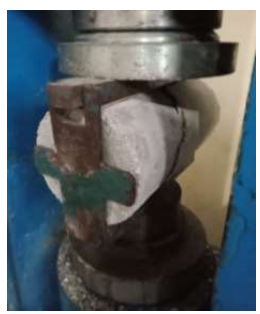

Fig.3. Tensile Testing
Table 2. Normal Tensile Strength (Control)

\begin{tabular}{|l|l|l|}
\hline Test Objects & $\begin{array}{l}\text { Maximum } \\
\text { Load (kN) }\end{array}$ & $\begin{array}{l}\text { Split Tensile } \\
\text { Strength } \\
\text { (MPa) }\end{array}$ \\
\hline TB1-1 & 160 & 7.111 \\
\hline TB1-2 & 120 & 5.333 \\
\hline TB1-3 & 120 & 5.333 \\
\hline TB1-4 & 130 & 5.778 \\
\hline TB1-5 & 160 & 7.111 \\
\hline
\end{tabular}

Table 3. Joint Tensile Strength

\begin{tabular}{|l|l|l|}
\hline Test Objects & $\begin{array}{l}\text { Maximum } \\
\text { Load (kN) }\end{array}$ & $\begin{array}{l}\text { Split Tensile } \\
\text { Strength } \\
\text { (MPa) }\end{array}$ \\
\hline TB1-1 & 100 & 4.444 \\
\hline TB1-2 & 60 & 2.667 \\
\hline TB1-3 & 90 & 4.000 \\
\hline TB1-4 & 70 & 3.111 \\
\hline TB1-5 & 80 & 3.556 \\
\hline
\end{tabular}

As shown in Figure 4, the concrete test object made of pumice sand experienced a large crack in the center of the cylinder at maximum load and even tended to crumble.

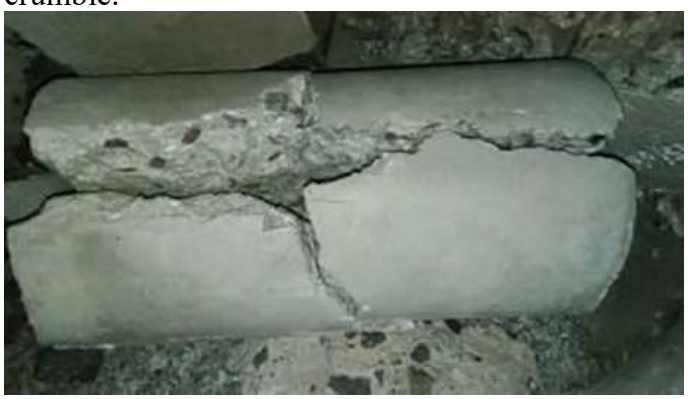

Fig.4. The crack pattern in the test object

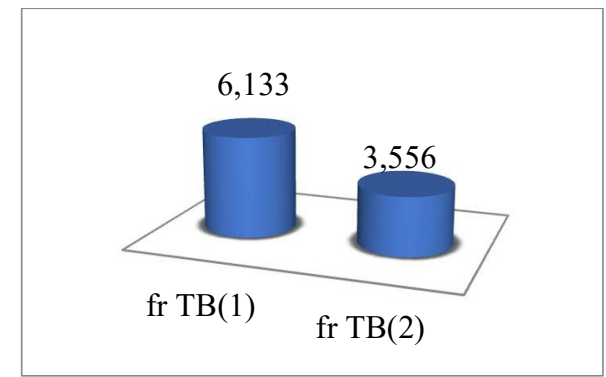

Fig.5. Comparison of Normal Splitting Tensile Strength (Control) and Joint Splitting Tensile Strength

Figure 5 showed that the joint splitting tensile strength was $3.556 \mathrm{MPa}$, while the normal splitting 
tensile strength (control) was $6.133 \mathrm{MPa}$. This indicated that there was a decrease in tensile strength by $42.02 \%$.

\section{Conclusion}

The use of pumice sand as fine aggregate in the concrete mixture resulted in a normal splitting tensile strength of 6.133 $\mathrm{MPa}$ and a joint splitting tensile strength of 3.556 $\mathrm{MPa}$. In other words, there was a decrease in tensile strength by $42.02 \%$ in the concrete connection.

\section{References}

[1] A. K. Salim, M. A. Darmawan, and H. Wibowo, "Analisa Perbandingan Biaya Perkerasan Kaku dan Perkerasan Lentur Pada Proyek Jalan Middle Ring Road Kota Makassar,” J. Tek. Sipil Macca, vol. 5, no. 1, pp. 41-47, 2020.

[2] R. Rizqurrachman, R. Djmaluddin, and S. A. Sasmita, "Pengaruh Beton Serat Yang Menggunakan Bentonit Terhadap Kekuatan Perkerasan Kaku," J. Sains dan Teknol., vol. 3, no. 1, pp. 92-98, 2014.

[3] A. K. Fauzi, E. Eswan, and S. Suratmi, "Perencanaan Perkerasan Kaku Dengan Beton Precast Sebagai Alternatif Percepatan Konstruksi Perkerasan Jalan," Tek. Sipil dan Arsit., vol. 1, no. 1, pp. 1-13, 2018.

[4] R. Riduan, E. Sulandri, and Su. Sumiyatinnah, "Studi Kuat Tekan Dan Kuat Lentur Beton Pada Perkerasan Kaku Terhadap Variasi Saringan Agregat Kasar," JeLAST, pp. 1-12, 2002.

[5] I. Indrayani, A. Herius, A. Hasan, and A. Mirza, "The Effect of Addition on Pumice and Fiber on Compressive and Fluxural Strength Precast Lightweight Concrete," Sci. Technol. Indones., vol. 5, no. 1, pp. 14-17, 2020.

[6] C. Niken, "The Behaviour Of Coak Connection Model On The Beam Applied For Precast Concrete," Din. Tek. Sipil, vol. 8, no. 2, pp. 149$161,2012$.

[7] N. Nuroji, B. H. Setiadji, and W. Aktorina, "Comparison of Precast and Conventional Concrete Rigid Pavements Using Analytical Hierarchy Process (AHP)," Media Komun. Tek. Sipil, vol. 26, no. 2, pp. 212-219, 2021.

[8] A. Gaus, I. Imran, C. Anwar, and L. Novianti, "Experimental Study of the Use of Pumice Sand in the Rigid Pavement," EPI Int. J. Eng., vol. 2, no. 1, pp. 61-66, 2019.

[9] A. Gaus, M. A. Sultan, R. Hakim, and I. Anggreni, "Substitusi Parsial Batu Apung Sebagai Agregat Kasar Pada Campuran Beton,” J. Tek. Sipil Univ. Teuku Umar, vol. 6, no. 2, pp. 11-19, 2020.

[10] C. Sutowo, S. Kirono, and T. Susanto, "Analisa Kekuatan Material Pada Aplikasi Dowel Jalan Beton," Sintek J., vol. 8, no. 2, pp. 1-7, 2014.

[11] M. A. Sultan, K. Kusnadi, and M. T. Yudasaputra, "Effect Of Pressure On Making Of Cemen Bricks from Pumice," Int. J. Civ. Eng. Technol., vol. 9, no. 5, pp. 1084-1091, 2018.

[12] SNI 03-3449, Tata Cara Rencana Pembuatan
Campuran Beton Ringan Dengan Agregat Ringan. 2002.

[13] M. Ardan, "Kajian penggunaan batu apung dan styrofoam sebagai bahan pengganti agregat kasar pada perencanaan beton ringan," Arbitek, vol. 2, no. 2, pp. 1-4, 2016.

[14] M. A. Sultan, A. Gaus, R. Hakim, and I. Imran, "Review of The Flexural Strength of Lightweight Concrete Beam Using Pumice Stone as of Substitution," Int. J. GEOMATE, vol. 21, no. 85, pp. 154-159, 2021.

[15] A. Gaus, Imran, and C. Anwar, "Analysis of the Mechanical Properties of Concrete Beams That Use Pumice as a Partial Substitution of Concrete Mixtures," J. Phys. Conf. Ser., vol. 1569, no. 4, 2020.

[16] A. Gaus, I. Imran, and C. Anwar, "The Effects of The Use of Pumice on Precasct Concrete Mixture For Highway Drainage," Int. J. Civ. Eng. Technol., vol. 10, no. 11, pp. 177-183, 2019.

[17] I. Rochani, A. Prasetyo, and A. Kurniawan, "Pemanfaatan Batu Apung (Pumice) Lombok dan Bakteri (Baccillus Subtilis) Sebagai Agent Perbaikan Kerusakan Retakan Beton," Maj. Geogr. Indones., vol. 30, no. 1, pp. 49-57, 2016.

[18] SNI 03-2491, "Metode pengujian kuat tarik belah beton," Badan Standar Nas. Indones., p. 14, 2002. 